\title{
Religious "irrationality" and civil liberties
}

\author{
by John Warwick Montgomery
}

$\mathrm{T}$ he theme of the Ecclesiastical Law Society's 2010 Day Conference, held on March 13 in London, was "Freedom of religion: protection or equality?" One of the speakers, Lucy Vickers, professor of law at Oxford Brookes University and specialist on religious discrimination in the workplace, declared that in her opinion the fundamental ground for legally protecting religious belief and practice is the essential irrationality of religious positions: since their truth cannot, unlike scientific views, be demonstrated, they need the protection of the law even more than do other ideas. Another speaker, Christopher McCrudden, professor of human rights law at the University of Oxford, indicated that he felt very uncomfortable with this argument, though there was no time at the conference to go into the issue in depth.

Then, a little over a month later (April 29), Lord Justice Laws issued his opinion in the case of McFarlane $v$ Relate Avon Ltd [2010] EWCA Civ B1 on appeal from the Employment Appeal Tribunal. Gary McFarlane, a relationships counselor in Bristol with strong evangelical Christian beliefs, had refused to provide sexual counseling to homosexual couples; as a result, he was dismissed by the Relate Avon organisation, whose position was upheld by the Employment Tribunal. Lord Justice Laws denied McFarlane's subsequent application to have his case heard by the Court of Appeal. The Lord Justice gave his ratio as follows: " $[\mathrm{I}] \mathrm{n}$ the eye of everyone save the believer religious faith is necessarily subjective, being incommunicable by any kind of proof or evidence. . . . [I] lies only in the heart of the believer, who is alone bound by it. No one else is or can be so bound, unless by his own free choice he accepts its claims. The promulgation of law for the protection of a position held purely on religious grounds cannot therefore be justified. It is irrational, as preferring the subjective over the objective" (paras 23-24).

These remarks created a considerable flap in the press, and former Archbishop George Carey took sharp issue with Lord Justice Laws' refusal to allow McFarlane's appeal. Some critics reasoned ad hominem, condemning Laws LJ on the basis of his reputation as a "legal activist."

But the especially interesting aspect of the decision is that, whilst agreeing entirely with Professor Vickers' view that religion is essentially subjective, and therefore unprovable and irrational, Laws LJ concludes that, instead of particularly deserving the protection of the law, religious claims must not be upheld legally against the (nonreligious) views of others. In other words, from the premise of religious irrationality, Vickers and Laws draw precisely opposite conclusions!

In the present essayist's view, neither Vickers nor Laws is correct, and for three compelling reasons: (1) It is incorrect to suppose that ideological conflicts in society pit "religious" beliefs against "non-religious" positions. (2) Religious beliefs are not necessarily irrational. (3) A proper basis for the protection - and the limitation - of religious practices must be found in an entirely different realm from that of supposed "religious irrationality." Let us briefly speak to each of these points.

1. The 20th-century theologian Paul Tillich stressed that there are in fact no atheists, since everyone has an "ultimate concern" — a value system determining his or her actions individually and societally. Thus, in McFarlane, Relate Avon, no less than McFarlane himself, held religious convictions-for Relate Avon, that homosexual relationships are ethically proper and as such deserve the benefits of sexual counseling no less than heterosexual relationships. Lord Justice Laws himself therefore acted irrationally in rejecting on grounds of religious irrationality McFarlane's overt religiosity in favour of Relate Avon's unstated, but no less religious, value system.

2. As for the claim by Vickers and Laws that religions are per se irrational, we might paraphrase George Orwell: all religions are equal, but some are more equal than others. There are indeed religions such as Buddhism that rely 100 per cent on personal, subjective experience as verification for their beliefs, as well as cultic movements such as Scientology having no way of objectively demonstrating the factuality of their doctrines (eg, that "body thetans" are the product of Xenu of the Galactic Confederacy and need to be treated through therapeutic "auditing" processes). But this is hardly a description all religious phenomena. An obvious counter-example is classic Christian faith, which centres on the historical facts of Jesus' life, death, and resurrection. The centuries-old discipline of Christian apologetics has offered powerful objective evidences for the truth of the Christian worldview; one thinks of the work of Pascal, 
William Paley, John Henry Newman, C S Lewis, Richard Swinburne-and lawyers such as Hugo Grotius (De veritate religionis Christianae), Simon Greenleaf (The Testimony of the Evangelists) — and Sir Norman Anderson, late director of the University of London's Institute of Advanced Legal Studies (The Evidence for the Resurrection). In recent years, the arguments for cosmic, universal "intelligent design" as presented by scientists such as William Dembski and Francis Collins have brought even distinguished atheistic philosophers (eg, Antony Flew) to belief in God.

3. Where, then, should one go to find an adequate basis for the protection of religious beliefs and practices-and proper grounds for limiting them? The answer is not to label religion as "irrational" and then to draw positive or negative conclusions from that characterisation, but rather to consider far more carefully the proper function of law in general in an open society. As political philosopher John Rawls emphasised by way of his First Principle of Justice (that dealing with civil liberties): "Each person is to have an equal right to the most extensive scheme of equal basic liberties compatible with a similar scheme of liberties for others." This means that unless one's belief or desired activity — including religious belief and activity — hurts others, it should be allowed. It also means that if the courts can find a way for a belief or activity to function without significant hurt to others, that belief or activity should be legitimated. In the McFarlane matter, therefore, since other relationship counsellors holding worldviews other than McFarlane's could readily treat the homosexual couples, McFarlane should have been allowed to retain his position-respect being shown to his personal beliefs by allowing him to give sex therapy only to heterosexual couples. (This is in line with medical practice in many civilized countries, where physicians and nurses opposing abortion do not have their public hospital privileges taken away, but are exempted from performing abortions and instead are assigned to perform other medical procedures.)

There is a further consideration of the greatest consequence to the judicial evaluation of religious belief and practice. That principle is encapsulated in a celebrated remark attributed to Voltaire: "I may not agree with what you say but I will defend to the death your right to say it." In an open society, even beliefs regarded by some as "irrational" need to be tolerated. Why? Because of the inherent dignity of the human persons holding those ideas. We need a free marketplace of ideas, not a society where some ideas (religious ones, for example) are given such second-class status that actions dependent on them are per se removed from legal protection- - even when their alleged harm to the society cannot be demonstrated. Today, in certain European states, one can be jailed for unpopular ideas (holocaust revisionism, for example); such obnoxious notions ought to be refuted in the public marketplace of ideas, not repressed by law. Religious beliefs, even those we disagree with, need to expressed — and practiced — in an open society. And, surely, those religious positions with solid, objective evidence in their behalf must not suffer ostracism simply because of their religious label! Otherwise, political correctness will prevail, and political correctness is no less a religion because it does not use that terminology. Indeed, in many ways it is far more dangerous to the public weal than are the religious ideas and practices it endeavours to repress.

John Warwick Montgomery

Professor Emeritus of Law and Humanities, University of Bedfordshire; Distinguished Professor, Patrick Henry College (Virginia, USA); author of Human Rights and Human Dignity (www.ciltpp.com)

\title{
Articles for Amicus Curiae
}

Amicus Curiae welcomes contributions, which should be accompanied by the name and contact details of the author. The journal publishes articles on a wide variety of issues, ranging from short pieces of 700-1,200 words and longer articles of 4,000 words of so (the upper limit can be extended where appropriate). Articles should be written in an informal style and without footnotes.

\author{
Anyone interested in submitting a piece should email Julian Harris \\ (julian.harris@sas.ac.uk).
}

